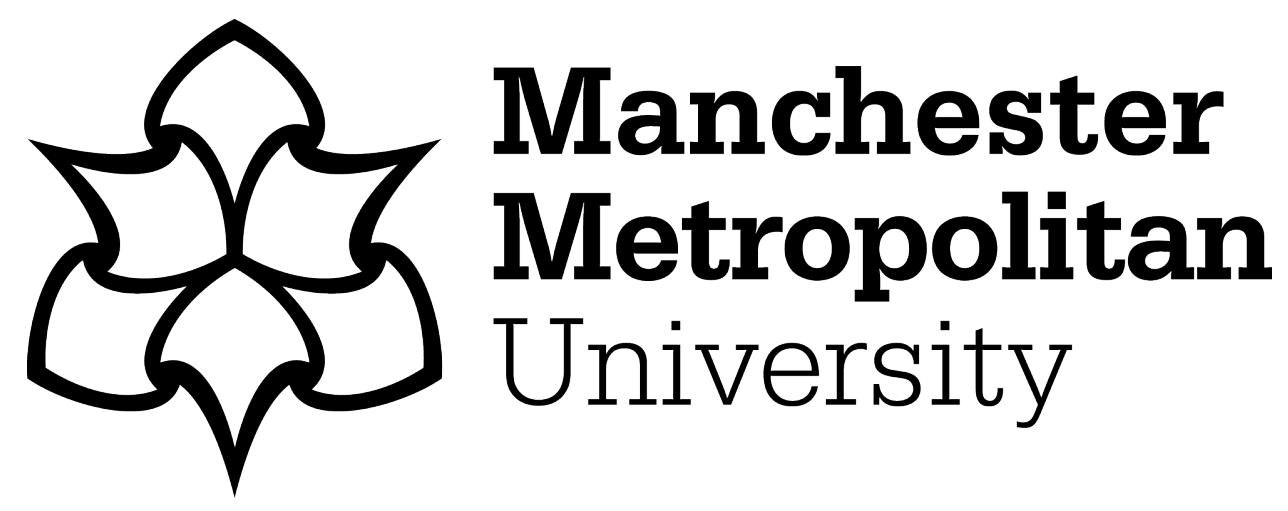

Strickland, Lloyd ORCID logoORCID: https://orcid.org/0000-0003-2560-6909 (2021) Book review: "God, Evolution, and Animal Suffering" by Bethany Sollereder. Religious Studies, 57 (4). pp. 776-779. ISSN 0034-4125

Downloaded from: https://e-space.mmu.ac.uk/624363/

Version: Accepted Version

Publisher: Cambridge University Press (CUP)

DOI: https://doi.org/10.1017/S0034412519000775

Please cite the published version 


\section{Bethany N. Sollereder, God, Evolution, and Animal Suffering: Theodicy Without a Fall (New York: Routledge, 2019). Pp. 206. \$140.00 (Hbk). ISBN 9781138608474.}

For almost as long as Christian thinkers have been vexed by the problem of evil, their attention has scarcely wavered from human pain and suffering and how to square this with an all-powerful, all-knowing, all-loving God. Only in the last few decades has the problem posed by animal suffering been given any meaningful consideration, and this has resulted in a spate of recent books and articles on the topic, most notably Michael Murray's Nature Red in Tooth and Claw (2008), Christopher Southgate's Groaning of Creation (2008), and Elizabeth Johnson's Ask the Beasts: Darwin and the God of Love (2014). To these we may now add Sollereder's God, Evolution, and Animal Suffering, which benefits enormously from the work of these (and other) pioneers without being beholden to any particular one.

With regard to animal suffering, Sollereder's book contains both a negative and a positive thesis. The negative thesis, the subject of chapter 2 , is that the commonly held view that a fall disrupted or corrupted God's peaceful creation by introducing violence, death, and suffering, is mistaken. While Sollereder accepts a human and satanic fall, she rejects a cosmic fall, that is, a corruption of the whole created order due to (but not directly caused by) the human or satanic fall (14). To those who suggest that suffering found its way into creation due to some kind of oppositional force, whether chaos or satanic, she points to the numerous scriptural passages which state that the world and all that is in it is God's handiwork and under his dominion. And to those who suggest that the world was corrupted by the curse of the ground mentioned in Genesis 3, she argues, through deft lexical analysis, that the curse was lifted following the flood recorded in Genesis 8, and that therefore 'One cannot look here [sc. to God's cursing of the ground in Genesis 3] for an explanation of the abundant suffering of the non-human world' (30).

Sollereder's positive thesis is developed in chapters 4, 5 and 6. Following in the footsteps of Murray and Southgate, Sollereder insists that only a compound model will succeed in addressing non-human suffering. The key elements of Sollereder's compound are these:

1. God's love of his creation

2. God's presence in the world, as co-sufferer and shaper of meaning

3. Universal redemption

The idea that God loves his creation is a familiar one, but Sollereder - like Southgate before her - sees it as the key to understanding God's decision to create a world driven by evolutionary processes, with all of the suffering that entails. After all, as Sollereder notes, true love precludes one having complete control over the beloved, though it does allow for direction, encouragement, and persuasion, all methods she thinks God uses in preference to direct control or manipulation (94). At the heart of this claim is a version of kenotic theology, according to which God voluntarily self-limits himself in various ways in order to allow his creation to develop freely, independently of his will. Drawing on the work of Polkinghorne and Southgate, Sollereder claims that God opts to create a world that creates itself, a world in which creatures have some autonomy in working out their own survival, autonomy which contributes to the evolutionary process. She stresses that it was God's choice to grant this autonomy rather than the result of any essential lack of power on God's part, as process theologians maintain.

The second element of Sollereder's model considers God's activity and presence in the world. Key here is the claim that God accompanies every creature in every moment of its existence and is thus their companion in suffering, a familiar motif in recent attempts by 
theologians to address animal suffering, for example in the works by Southgate and Johnson mentioned above. Sollereder also envisages God as 'active in shaping the meaning of events' (144), and thus cautions against our supposing that the meaning of any event is already fixed, whether to us or to God, as he will seek to craft new meanings as creation unfolds.

Accordingly, we should not suppose that the story of the world and the animal suffering therein is ready to be told in its final form, as God has not yet finished it.

This leads to the third element of Sollereder's model, namely the completion of God's creative activity through redemption, which she construes not merely in terms of renewal but in terms of a transformation of individual creatures into something far greater than they were in this life. While it has become commonplace for those tackling the problem of animal suffering to appeal to redemption at the eschaton, some, such as Southgate, restrict it to sentient creatures only. Meanwhile, others, such as Johnson, conceive it as extending to all creatures, and Sollereder follows suit, arguing that as God loves each creature individually, he will redeem each and every one: 'The scope of redemption is universal because a universal redemption is required by the ubiquitous love of God' (163). While she allows that redemption will heal the suffering of animals, she is at pains to stress that it should not be considered as compensation for this suffering, but rather as the fullest expression of God's love, which transforms all the world's evil, harm, and disvalue 'into the love, harmony, and diversity of the kingdom of God' (178).

As should be clear from the foregoing, Sollereder's model leans heavily on ideas formulated and developed by a number of others working in the same field. This is not to suggest that there is nothing original in her model, however. Once one dives into the detail one finds much that is novel, such as her construal of redemption in terms of fractal mosaics, in which individual creatures are thought of as forming a picture from which one can zoom out (as it were) to a broader picture which captures the relationships between creatures and from which one can zoom out still further to see the picture of the interaction of these relationships. According to Sollereder, all of these fractal mosaics are disassembled at the end of time, and from them all God forms a new, harmonious picture, at the point of the resurrection (166-7).

While Sollereder's book will (deservedly) attract much attention for the impressively detailed model it contains, it might also serve to open a debate about the nature of theodicy itself. The subtitle of the book - Theodicy Without a Fall - would lead one to suspect that Sollereder intends her model as a theodicy, yet in the introduction she describes the book as 'an exploration of theology relating to suffering and creation, rather than a traditional theodicy or defence' (3). In the same vein, a little later in the introduction she claims that her 'overall goal is not to defend or justify God against attacks, but to paint a picture of God and the world that incorporates the suffering and the joy, the death and the life, the loss and the redemption that is revealed through investigation of the natural world and the Christian story' (10). So does Sollereder intend her model as a theodicy or not? The evidence is mixed throughout. For example, in chapter 3, a lengthy and illuminating survey of other thinkers' attempts to square animal suffering with the existence of God, Sollereder depicts the project of theodicy in stark terms as an enterprise shorn of theological commitments (57), which contrasts sharply with her own approach, drawing heavily as it does upon resources from systematic theology and biblical studies and very little from philosophy. Further on in the book she again draws a clear distinction between her approach and that of traditional theodicy (93), yet this does not prevent her from occasionally describing her model as a theodicy (e.g. 183). Sollereder's vacillation is no doubt due to the fact that since Leibniz first coined the term, a theodicy has typically been thought of a philosophical justification of God in the face of the world's evil, a description that, by Sollereder's own admission, does not obviously apply to her model. Yet her model contains a more plausible justification than many of those 
offered heretofore, not in spite of the fact that it is rooted much more deeply in theology than in philosophy but arguably because of it. Therefore, what Sollereder shows, perhaps inadvertently, is that the project of theodicy stands a better chance of thriving as part of a broader theological system than it does as the standalone philosophical exercise it so often has been.

\section{Lloyd Strickland}

Manchester Metropolitan University

L.Strickland@mmu.ac.uk 